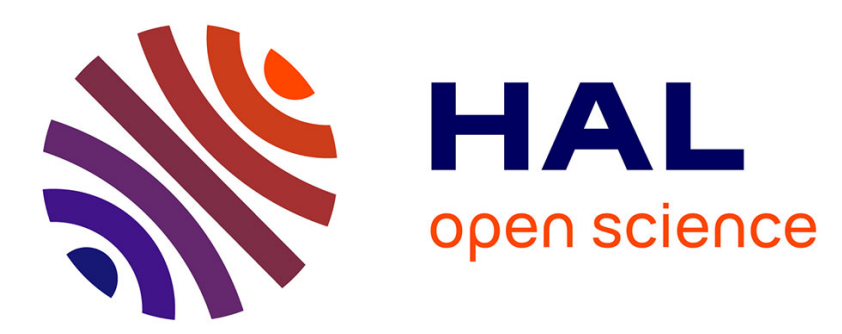

\title{
Changes in parvalbumin immunoreactivity with aging in the central auditory system of the rat
}

\author{
Ladislav Ouda, Rastislav Druga, Josef Syka
}

\section{To cite this version:}

Ladislav Ouda, Rastislav Druga, Josef Syka. Changes in parvalbumin immunoreactivity with aging in the central auditory system of the rat. Experimental Gerontology, 2008, 43 (8), pp.782. 10.1016/j.exger.2008.04.001 . hal-00499053

\section{HAL Id: hal-00499053 https://hal.science/hal-00499053}

Submitted on 9 Jul 2010

HAL is a multi-disciplinary open access archive for the deposit and dissemination of scientific research documents, whether they are published or not. The documents may come from teaching and research institutions in France or abroad, or from public or private research centers.
L'archive ouverte pluridisciplinaire HAL, est destinée au dépôt et à la diffusion de documents scientifiques de niveau recherche, publiés ou non, émanant des établissements d'enseignement et de recherche français ou étrangers, des laboratoires publics ou privés. 


\section{Accepted Manuscript}

Changes in parvalbumin immunoreactivity with aging in the central auditory system of the rat

Ladislav Ouda, Rastislav Druga, Josef Syka

PII:

S0531-5565(08)00094-6

DOI:

10.1016/j.exger.2008.04.001

Reference:

EXG 8466

To appear in:

Experimental Gerontology

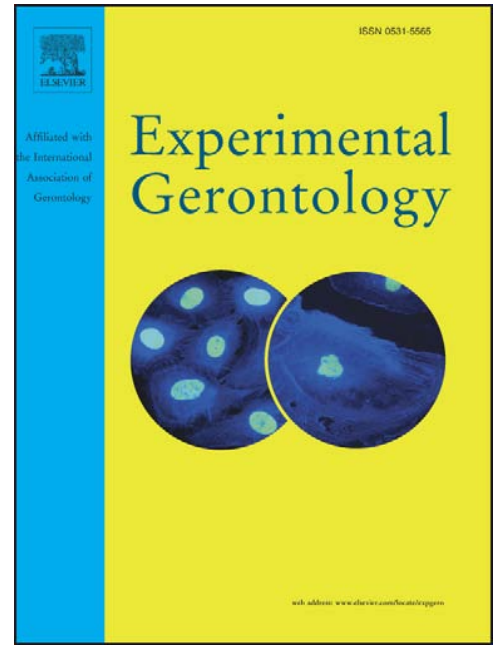

Received Date: $\quad 31$ January 2008

Revised Date: $\quad 21$ March 2008

Accepted Date: $\quad 1$ April 2008

Please cite this article as: Ouda, L., Druga, R., Syka, J., Changes in parvalbumin immunoreactivity with aging in the central auditory system of the rat, Experimental Gerontology (2008), doi: 10.1016/j.exger.2008.04.001

This is a PDF file of an unedited manuscript that has been accepted for publication. As a service to our customers we are providing this early version of the manuscript. The manuscript will undergo copyediting, typesetting, and review of the resulting proof before it is published in its final form. Please note that during the production process errors may be discovered which could affect the content, and all legal disclaimers that apply to the journal pertain. 


\section{Changes in parvalbumin immunoreactivity with aging in the central auditory system of the rat}

Ladislav Ouda $^{1}$, Rastislav Druga ${ }^{2}$, Josef Syka ${ }^{1}$

${ }^{1}$ Department of Auditory Neuroscience, Institute of Experimental Medicine, Academy of Sciences of the Czech Republic, Prague, Czech Republic

${ }^{2}$ Department of Functional Anatomy, $2^{\text {nd }}$ Medical Faculty, Charles University, Prague, Czech Republic

\section{Address for correspondence:}

Ladislav Ouda, M.D.

Institute of Experimental Medicine, Academy of Sciences of the Czech Republic,

Vídeňská 1083, 14220 Prague, Czech Republic.

Phone: +420241062690

Fax: +420241062787

Email: ouda@biomed.cas.cz

Running title: Aging and parvalbumin in rat auditory brain

Keywords: calcium binding proteins, parvalbumin, aging, inferior colliculus, medial geniculate body, auditory cortex, rat 


\section{ABSTRACT}

Changes in the levels of calcium binding proteins are known to occur in different parts of the brain during aging. In our study we attempted to define the effect that aging has on the parvalbumin-expressing system of neurons in the higher parts of the central auditory system. Age-related changes in parvalbumin immunoreactivity were investigated in the inferior colliculus (IC), medial geniculate body (MGB) and auditory cortex (AC) in two rat strains, normally aging Long Evans (LE) and fast aging Fischer 344 (F344). The results demonstrate that the changes in PV-immunoreactivity are strain-dependent with an increase in the number of PV-immunoreactive (PV-ir) neurons occurring in the inferior colliculus of old LE rats and a pronounced decline in the number of PV-ir neurons appearing in the auditory cortex of aged F344 animals. In some parts of the AC of old F344 animals no PV-ir neurons were present at all. The number of PV-ir neurons in the MGB in all examined animals was very low independent of the strain and age. The loss of PV-ir neurons in the auditory cortex of Fischer 344 rats with aging may contribute to the substantial deterioration of hearing function in this strain. 


\section{INTRODUCTION}

The calcium binding proteins (CBP), calbindin (CB), parvalbumin (PV) and calretinin (CR), are among the major fast cytoplasmatic calcium buffers in the central nervous system (for review see Baimbridge et al., 1992). The disruption of neuronal calcium homeostasis and consequent molecular events affect neuronal viability and synaptic plasticity and may represent early steps in the development of neuronal degeneration (Foster, 2007). Changes in calcium homeostasis in the brain during aging are thought to be tightly linked to a decline in neuronal performance (Khachaturian, 1989; Verkhratsky and Toescu, 1998).

The distribution of parvalbumin-immunoreactive (PV-ir) neurons in the central nervous system of the rat was first described in a summary by Celio (1990). PV-ir neurons were found to be present in most parts of the central auditory system with the exception of the medial geniculate body (Celio, 1990; Covenas, et. al., 1991). Their distribution seems to be complementary to calbindin with a predominant distribution of PV in primary and CB in nonprimary areas as also described in mice (Cruikshank et al., 2001), monkeys (Jones, 2003) and humans (Tardif et al., 2003). Most PV-ir cells in the central auditory system, as in other parts of the central nervous system, are interneurons (Golgi type I cells) highly colocalized with the neurotransmitter gamma-aminobutyric acid - GABA (Celio, 1986; DeFelipe and Jones, 1992; Kosaka et al., 1987; Kawaguchi and Kubota, 1998).

Several lines of evidence indicate that fast-spiking GABA-ergic cortical basket cells that express parvalbumin and form most of the PV-ir neurons are essential for the generation of gamma oscillations, which are thought to provide a temporal framework for information processing in the brain (Kawaguchi and Kubota, 1998, Bartos et al., 2007). In the hippocampus parvalbumin-expressing basket cells represent approximately $20 \%$ of GABAcontaining inhibitory interneurons (Freund and Buzsáki, 1996) and form an extensive, 
mutually connected interneuronal network interconnected with gap junctions (Fukuda et al., 2006). Decreases in the presence of parvalbumin-ir neurons have been described in several major illnesses of the human brain such as schizophrenia and epilepsy (for review see Woo and $\mathrm{Lu}, 2006$; Lewis et al., 2005). On the other hand, in human neocortex from individuals without any signs of neurological or psychiatric disorders, Bu et al. (2003) found no agerelated changes in PV-immunoreactivity with aging in contrast to a decrease in the number of calbindin- and calretinin-ir neurons.

Age-related changes in CBP in different cortical and subcortical structures have also been described in laboratory animals. Hwang et al. (2003) reported a decline in the number of PVir neurons together with other morphological changes in the olfactory bulb of aging rats. In the same species a reduction in the cross-sectional area and a decrease in the numerical density of PV-ir neurons were found in the cingulate cortex (Krzywkowski et al., 1995). A significant loss of CB-ir neurons, but only small changes in the occurrence of PV-ir neurons, was observed in the aged rabbit hippocampus (DeJong et al., 1996). In the brain of hamsters, calretinin and parvalbumin mRNA expression remained unchanged during aging, while calbindin - D28k mRNA expression was decreased (Kishimoto et al., 1998). Age-related changes in the levels of the calcium binding proteins are well characterized in the cochlear nuclei and inferior colliculus of mice. The reported changes were strain-dependant for all three proteins in cochlear nuclei (Idrizbegovic 2003,2004) and for calretinin in the IC (Zettel 1997).

The age-related changes in the levels of CBP in the auditory cortex are not well known. In contrast, a substantial decrease with aging in the levels of other markers in the auditory cortex of rats was reported in the case of GABA (Ling et al. 2005), NADPH-diaphorase (Ouda et al. 2003) and acetylcholine (Stemmelin et al., 2000). In our study we evaluate age-related 
changes in parvalbumin expression in the higher parts of the central auditory system in two rat strains, normally aging Long Evans (LE) and fast aging Fischer 344 (F344).

\section{MATERIALS AND METHODS}

\section{Animals}

Nineteen male rats (10 Long Evans, 5 young animals 3-5 months old and 5 aged animals 27-30 months old, and 9 Fischer 344, 5 young animals 3-5 months old and 4 aged animals 22 months old) were used in the experiments. All Fischer 344 rats were purchased at 2 months of age from Charles River Deutschland (Charles River Wiga GmbH, Sulzfeld, Germany) and then reared in-house under standard rearing conditions without any noise exposure. All Long Evans rats were obtained from our local facility at the age of 2 months and reared in-house under the same conditions. No signs of any middle ear infection were present in any animal during their stay in our animal facility. The care and use of animals and all experimental procedures followed the principles of laboratory animal care and were performed in compliance with the guidelines of the Ethical Committee, Institute of Experimental Medicine, Academy of Sciences of the Czech Republic, and the Declaration of Helsinki.

\section{Parvalbumin immunohistochemistry}

Under deep anesthesia (pentobarbital, $50 \mathrm{mg} / \mathrm{kg}$, i.p.), animals were transcardially perfused with saline followed by $4 \%$ paraformaldehyde fixative in $0.1 \mathrm{M}$ phosphate buffer (pH 7.4). The brains were removed within 15 min of perfusion, postfixed 1 hour at $4^{\circ} \mathrm{C}$ (same fixative) and then cryoprotected with $30 \%$ sucrose in phosphate buffer overnight. Coronal sections (40 $\mu \mathrm{m}$ thick) were cut with a freezing microtome.

Free-floating sections were preincubated in a blocking solution and then incubated for $48 \mathrm{~h}$ in $\operatorname{PBS}\left(4^{\circ} \mathrm{C}\right)$ containing anti-parvalbumin $(1: 1000$, Sigma, St. Louis, MO). Sections were incubated first with a biotinylated secondary antibody (Vector), diluted 1:200, for $90 \mathrm{~min}$, and 
then with avidin-biotin-peroxidase complex (1:100, Vector) for $1 \mathrm{~h}$ at room temperature. The peroxidase reaction was visualized with $0.02 \%$ diaminobenzidine and $0.01 \%$ hydrogen peroxide for $3 \mathrm{~min}$. Sections were mounted on slides, dehydrated and coverslipped.

Each second section from one animal from each group was stained for Nissl substance to visualize global age-related changes in the total number of neurons and to ensure the positions of the auditory cortical areas.

\section{Stereological quantification}

Parvalbumin immunoreactivity was examined in all sections containing the IC, MGB and auditory cortex delineated according to anatomical atlases (Zilles, 1985; Paxinos and Watson, 1998) and with the help of Nissl-stained sections (topographical borders of cortical auditory areas). Sections for the auditory cortex were sampled from bregma $-4.2 \mathrm{~mm}$ to bregma -5.8 $\mathrm{mm}$ (Zilles, 1995), identified by measuring 2.0-2.5 $\mathrm{mm}$ from the rhinal fissure for Te3 and 3.5-4.0 $\mathrm{mm}$ for Te1. As an auxiliary criterion, the line going through the dorsal margin of the diencephalon demarcated the control dorsal (upper) border of the auditory cortex. For the IC, sections were sampled from bregma -8.0 to $-9.2 \mathrm{~mm}$ and for the MGB from bregma -5.0 to $6.2 \mathrm{~mm}$ (Fig.1A,B,C). To estimate the total number of PV-ir neurons, an unbiased stereological method, the optical fractionator, was used (West et al., 1991; for review see Mayhew and Gundersen, 1996). The optical fractionator method is unaffected by tissue shrinkage, and therefore it was not necessary to measure this variable. Measurements were determined using bright-field microscopy (Leica DMRXA microscope) connected to a video camera, which transmitted the microscopic image to a monitor (Optronics, 1600x1200 px) coupled with Neurolucida software (MicroBrightField). Two sets of motors were connected to the microscope to move the section a known distance in the $\mathrm{x}$ - and $\mathrm{y}$-directions. The $\mathrm{z}$ direction was measured using a microcator. A 10x objective lens was used to delineate the regions of interest and the starting position of the counting frame. We adapted the 
Neurolucida-generated grid superimposed on the screen with the use of a random number table to establish the random starting position of the counting frame in the area of interest.

A $100 x$ oil-immersion objective was used and the appropriate counting frame superimposed on the screen. The counting frames used to obtain the sampling had the same size $\left(3880 \mu \mathrm{m}^{2}\right)$. The upper and lower surfaces of the sections were examined to determine if the margins of the tissue sections were depleted of neuronal nuclei, as suggested by Andersen and Gundersen (1999). The height of the optical dissector was constant at $10 \mu \mathrm{m}$, and the first and last $5 \mu \mathrm{m}$ of the section thickness were omitted from the analysis. Approximately 200 neurons per animal in each examined structure were counted (except for the MGB where only 30-50 neurons per animal were counted). Each neuron in the counting frame was counted when its nucleolus came to maximum focus. At maximum focus, the cell body was outlined by a cursor on the computer screen, and the morphological parameters and optical density were measured automatically using Neurolucida software. Only positive somas that exceeded $5 \mu \mathrm{m}$ in diameter and with a distinct nucleolus were counted and used for the analysis.

Although the counting of neurons was unbiased, the measurement of their volume might be connected with a small error. Because the sections were cut coronally, the requirement of an isotropic or vertical random orientation of the sections could not be accomplished (for review see Mayhem and Gundersen, 1996). However, in an older review (Gundersen et al., 1988), authors reported that the error should be negligible in such a case. The neuronal volume was estimated using the nucleator technique when the nucleolus was at maximum focus. The volume of the PV-ir soma was then calculated by averaging the third powers of intercept lengths and multiplying this average by $4 \times \pi / 3$ formula (Mayhem and Gundersen, 1996).

Variation in the background immunostaining affects the real values of the optical density of the neuronal soma. In studies of aging, there are not available specific "indifferent 
reference structures" in the brain for normalization, hence we calculated the normalized value of the optical density in each section as the ratio between the average optical density of the analyzed PV-ir neurons in the section and the average optical density of a corresponding number of immunonegative cells in the same section (compare Ling et al., 2005). In most cases the immunopositivity of the neurons was explicit; in a few disputable cases, a selected neuron was omitted from the analysis as "non-PV-ir" unless the measured optical density of its soma was higher than double of the average optical density of immunonegative cells in the same section.

\section{Statistical analysis}

The number of neurons, normalized values of the optical density and mean neuronal volumes were compared between young and old animals. In addition, comparison was made between Long Evans and Fischer 344 animals.

The results of statistical analysis are expressed as mean \pm S.E.M. The results and the significance of the differences between young and old animals of the same strain and between LE and F344 rats (young vs. young and old vs. old) was assessed by the non-parametric twotailed Mann-Whitney test with the use of GraphPad Prisma software (version 4.0). P values of 0.05 or less were considered statistically significant.

\section{RESULTS}

\section{Inferior colliculus}

PV-ir neurons were distributed throughout all three subdivisions of the IC. In the central nucleus of the IC (CIC), oval and disc-shaped neurons predominated with a large variation in the size of the neuronal somas; the intensity of their immunoreactivity varied from low to high. The majority of PV-ir neurons in the external cortex of the IC (EIC) were large spindle 
multipolar cells or smaller oval neurons, both in the 2nd and 3rd layesr of the EIC. Clusters of immunoreactive somas and neuropil in the 2nd layer of the EIC (Chernock et al., 2004) were clearly visible in the majority of examined animals of both strains. The highest number of PV-ir neurons was found in the CIC $\left(5520 / \mathrm{mm}^{3}\right)$ followed by the EIC $\left(3750 / \mathrm{mm}^{3}\right)$, while only occasional oval PV-ir neurons occurred in the dorsal cortex of the IC - DIC $\left(720 / \mathrm{mm}^{3}\right)$. The mean neuronal volume was largest in the EIC $\left(1260 \mu \mathrm{m}^{3}\right)$ followed by the CIC $\left(990 \mu \mathrm{m}^{3}\right)$ and DIC $\left(810 \mu \mathrm{m}^{3}\right)$. All data in parentheses apply to young LE rats. However, these features were generally present in all examined groups of animals.

Significant age-related changes were found only in the CIC (Fig. 2 A,B). In the old Long Evans rats the number of PV-ir neurons in the CIC was increased by $19 \%$ ( $\mathrm{P}=0.03$, Fig. 4A). This numerical change was associated with an increase in the optical density of PV-ir somas of $18 \%(\mathrm{P}=0.03)$ and a slight decrease in the neuronal volume (decrease of $7 \%$ from $990 \mu \mathrm{m}^{3}$, N.S.; Fig. 4C,E). In the Fischer 344 rats a non-significant tendency towards a decrease in the number of PV-ir neurons and no changes in their optical density with aging were found in the CIC (Fig. 4 B,D). In contrast to the LE rats, the volume of PV-ir neuronal somas was significantly smaller in old F344 animals in comparison with young ones (a decrease of $21 \%$ from 1030 to $815 \mu \mathrm{m}^{3}, \mathrm{P}=0.03$; Fig. $\left.4 \mathrm{E}, \mathrm{F}\right)$. The observed changes could not be attributed to any specific type of neuron.

\section{Medial geniculate body}

Both the dorsal and ventral divisions of the MGB contained only sparse small oval parvalbumin-positive neurons with a low intensity of immunostaining. Their number varied over the range of $120-150 / \mathrm{mm}^{3}$ in the ventral and $100-130 / \mathrm{mm}^{3}$ in the dorsal division of the MGB in young animals of both strains. Only a minority of examined sections contained any PV-ir neurons at all. The volume of PV-immunoreactive neurons in both the ventral and 
dorsal MGB was approximately $750-800 \mu \mathrm{m}^{3}$. In the medial division of the MGB practically no PV-ir neurons were seen in any of the examined animals regardless of age or strain. No remarkable age-related changes were observed in the parameters of PV-ir neurons in the MGB (Fig. 4).

\section{Auditory cortex}

In both strains, PV-ir cells were scattered throughout layers II-VI with only sparse immunoreactive neurons and fibers in layer I. The optical density of neuropil staining was highest in layers II and IV, followed by layer V. Layers III and VI exhibited a markedly lower optical density (Fig. 2 C,E). On average, the neuropil staining was more intense in the Te1 area compared to Te3, but the optical density of PV-ir somas showed no significant difference between these areas. The PV-ir cells were mainly medium-sized and exhibited moderate or strong immunoreactivity with less variability compared to the IC and no significant differences among layers. Most immunoreactive cells in all layers were oval and multipolar elements with diverse orientations of the dendrites. PV-ir cells also included a few triangular and spindle neurons. Primary dendrites could be followed in some neurons up to a distance of $100 \mu \mathrm{m}$ from the cell body, especially in the case of spindle neurons with processess perpendicular to the cortical surface. The number of PV-neurons was higher in the superficial layers (II-IV) than in the deep layers (V-VI), especially in Te3 area. These features were present in all examined groups of animals

In old Long Evans rats, we found in a few cases sections with no PV-immunoreactive neurons or with a highly reduced number of PV-ir neurons (reduced by more than $50 \%$ compared to the average numerical density in young rats) in fields within the Te1 or Te3 area. This resulted in a slight but non-significant average decrease in the numerical density in the Te1 and Te3 areas in old LE rats compared to young ones (Fig. 4A). The optical density of PV-ir somas in old Long Evans animals was non-significantly increased (Fig. 4C). 
In contrast to the findings in LE animals, in old F344 rats we observed substantially more sections with no PV-positive neurons or with a substantially reduced number of PV-ir cells (>50\%) within the auditory cortical areas Te1 or Te3 involving all layers (Fig. 2D,F). The reduction occurred non-preferentially in all types of PV-ir neurons. In more than one-third of the examined sections containing the Te1 and Te3 areas, we either did not find any PV-ir neurons or else they were very scarce. The parvalbumin-free fields extended through all cortical layers. Examination of serial sections revealed that parvalbumin-free fields occupied in some cases the majority of the Te3, Te1 or both areas in the examined hemisphere (Fig. 3). In all old F344 rats at least one auditory cortical area was affected to a certain degree. In nonaffected parts of the auditory cortex only a slight decrease in the number of PV-ir cell was found compared to young animals. However, these large deficits in the local occurrence of PV-ir neurons resulted in a significant reduction of their mean numerical density in the auditory cortex by $31 \%$ in comparison with young Fischer 344 rats $(\mathrm{P}=0.015$, Fig. 4B). In addition, similar deficits in the number of PV-ir neurons were also found in the visual cortical areas V1 and V2 and the retrosplenial cortex as captured in the examined sections. No fields devoid of PV-ir neurons were observed in young Fischer 344 rats. There were no changes in the optical density of PV-ir neuronal somas in aged F344 animals in comparison with young ones (Fig. 4D). Similarly, the mean volumes of PV-ir neurons in the auditory cortex were not different between young and old rats of either strain (about $950 \mu \mathrm{m}^{3}$ for LE animals and 900 $\mu \mathrm{m}^{3}$ for F344 rats).

When comparing the Long Evans and Fischer 344 strains (young vs. young and old vs. old animals), no other statistically significant differences were found with the exception of a lower number of PV-ir neurons in the AC of old $\mathrm{F} 344$ rats vs. old LE rats ( $\mathrm{P}=0.03)$. 


\section{Nissl staining}

In sections stained for Nissl substance, no noticeable age-related changes in the total number of neurons were observed in either strain. The number of neurons was found to be about $93000 / \mathrm{mm}^{3}$ in the IC, $55000 / \mathrm{mm}^{3}$ in the MGB, and $75000 / \mathrm{mm}^{3}$ in the AC. However, the number of examined animals (one for each group) was too low for any further statistical analysis. As well, no apparent changes in the thickness of the auditory cortex or in the crosssectional areas of the IC and MGB were observed in old animals.

\section{DISCUSSION}

Our results demonstrate significant age-related changes in parvalbumin immunoreactivity in the upper parts of the auditory pathway in the rat, which comprise changes in the number of PV-ir neurons, their optical density and the volume of PV-ir somas. In summary, the number of PV-ir neurons increased with age in the CIC in the Long Evans strain, whereas in the Fischer 344 strain a significant reduction was observed in the occurrence of PV-ir neurons in the AC with aging. Some parts of the AC in Fischer 344 rats were, in contrast to young animals, completely devoid of parvalbumin immunoreactivity.

Long Evans and Fischer 344 represent two rat strains with a wide variety of morphological, physiological and behavioral differences. For example, similarly to other inbred strains (Wistar, Sprague-Dawley and Dark-Agouti), Fischer 344 rats display large cognitive deficits in different tests of spatial memory in the Morris water maze in contrast to wild rats and Long-Evans rats (Harker and Whishaw, 2002). A more rapid and pronounced deterioration of hearing function with aging is found in the Fischer 344 strain in comparison with Long Evans rats, resulting in larger hearing threshold shifts, a decrease in the amplitude of click-evoked auditory brainstem responses, a diminution of distortion product otoacoustic emissions and a decrease in middle-ear compliance (Popelar et al. 2003, 2006). Age-related 
sensory deficits in F344 rats also include visual function, which is damaged due to retinal degeneration (DiLoreto et al, 1994).

In our experiments, significant differences were observed in the age-related changes in parvalbumin immunoreactivity between the F344 and Long Evans strains. The reduction in the numerical density of parvalbumin-ir neurons in the AC in aged F344 rats is in accordance with the prevailing tendency towards a decrease in the number of PV-ir neurons in other parts of the aging brain in rats, for example in the cingulate cortex, hippocampus and olfactory bulb (Krzywkowsky et al., 1995; Shetty and Turner, 1998; Hwang et al., 2003), although focal declines in immunoreactivity were not reported. In old Long Evans rats only a slight reduction in the number of PV-ir neurons was found in the AC, but, in contrast, such neurons were found in elevated numbers in the central nucleus of the IC. What this means for the function of the IC in old Long Evans rats remains to be determined. In any case, a similar increase in the number of $\mathrm{PV}$-ir neurons was found in aged $\mathrm{CBA} / \mathrm{CaJ}$ mice, a strain with preserved hearing function up to an advanced age, in the cochlear nuclei (Idrizbegovic et al., 2001). The authors argue for recruited new expression during aging in neurons originally immunonegative for calcium binding proteins. The up-regulation of calcium binding proteins should represent a buffering capacity against changes in intracellular calcium levels, while impaired calcium homeostasis is thought to play a critical role in cellular aging (Verkhratsky and Toescu, 1998; Toescu et al., 2004). In addition, the optical density which reflects immunostaining intensity of CIC neurons was found to be increased in Long Evans rats. This may either be connected with an increase in the expression of the protein or the result of an accumulation of parvalbumin due to the shrinkage of the cells (Krzywkowski et al., 1995). Another feature characteristic of aged PV-ir neurons in the rat might be a decline in the size of their somas with aging. In the IC of old Fischer 344 rats, we observed a significant decline in the volume of PV-ir somas, similar to that seen in the medial septum-diagonal band of the 
Broca region in the Sprague-Dawley rat strain (Krzywkowski et al., 1995). No apparent agerelated changes in the average cross-sectional size of the $\mathrm{CIC}$ found in both strains are consistent with previous observations in rat (Caspary et al., 1995) and mice (Willot et al., 1994).

An interesting analogy to the present findings in Long Evans vs. Fischer 344 strains of rat exists in mice when comparing the $\mathrm{CBA} / \mathrm{CaJ}$ and $\mathrm{C} 57 / \mathrm{BL} / 6 \mathrm{~J}$ strains. An age-related decline in calbindin-immunoreactivity was found in the medial nucleus of the trapezoid body only in C57 mice, not in CBA mice (O`Neill et al., 1997). With aging both strains show a decline in the number of calbindin-ir neurons in the IC, whereas calretinin-ir neurons increase with age only in the IC of CBA mice, not in C57 mice (Zettel et al, 1997). This up-regulation of calretinin is dependent on preserved sound-evoked activity, since in CBA mice bilaterally deafened in youth, the increase with age does not occur (Zettel et al., 2001). It remains to be investigated whether the age-related increase in the number of parvalbumin-ir neurons in the IC of old Long Evans rats, found in our experiments, is also dependent on sound-evoked activity.

The substantial loss of PV-ir neurons in the auditory cortex in Fischer 344 strain cannot be simply explained by a selective neuronal loss, because in sections stained for Nissl substance no significant numerical changes were present. This finding is in agreement with a paper by Merrill et al. (2001), who reported no significant changes in the total number of neurons in the cortex of old F344 rats in comparison with young animals. In addition, also Poe et al. (2001) in the rat sensorimotor cortex and Helfert et al.(1999) in the rat inferior colliculus did not reported any age-related decline in the total quantity of neurons but rather morphological and synaptic changes. Interestingly, staining for calbindin and calretinin did not reveal any numerical changes in the cortical areas of old F344 rats where PV-ir neurons were absent or 
nearly absent (our unpublished data), which supports the idea of a predominant selective loss of parvalbumin expression or parvalbumin-expressing neurons.

In the last few years, growing evidence has accumulated about the role of PV-ir neurons in the inhibitory networks generating gamma oscillations, especially in the neocortex and hippocampus, both in man and rat (Bragin et al, 1995; Buzsáki and Draguhn, 2004). Gamma oscillations $(30-100 \mathrm{~Hz})$ are thought to represent reference signals for temporal encoding, the sensory binding of features into a coherent percept and also for memory (for review see Bartos et al., 2007). In humans, alteration of GABA inhibitory transmission mediated by PVir interneuron networks has been shown to be involved in several disorders of the brain (Woo and Lu, 2006; Lewis et al., 2005). Parallel studies were performed in animal models: In the LPA1-deficient mice model of schizophrenia, a significant decrease in PV and GABA immunoreactivity was present in the entorhinal cortex, associated with a dramatic decrease in the power of gamma oscillations at the same location (Cunningham et al, 2006). In the rat methylazoxymethanol model of schizophrenia, the number of PV-ir neurons was significantly decreased in the prefrontal cortex but not in the hippocampus (Penschuck et al., 2006). In both animal studies, no changes in the number of CB-ir or CR-ir cells were found.

Following this logic, the observed reduction in PV and GABA immunoreactivity in the hippocampus (Shetty and Turner, 1998; Shi et al. 2004) could contribute to the cognitive deficits observed in aged Fischer 344 animals. The cognitive deficits were found mainly in spatial learning but also in fear conditioning and in odor discrimination tasks in this strain (Oler and Markus, 1998; Harker and Whishaw, 2002; Villarreal et al., 2004; LaSarge et al., 2007). In many tasks, a tone stimulus was used for fear conditioning (Oler and Markus, 1998; Villareal et al., 2004). Since old Fischer 344 rats are hearing-impaired with large hearing losses (Popelar et al., 2003, 2006; Buckiova 2007), the results of those experiments may also have been influenced by the limited hearing abilities of the aged animals. The relationship 
between a decline in hippocampal PV-ir neuronal networks and cognitive deficits in the same strain may suggest that the large decline in the number of PV-ir neurons in the auditory cortex in Fischer 344 rats could contribute to the deterioration of hearing function in these animals. In addition, findings of comparable deficits in the visual and retrosplenial cortices might suggest the contribution of PV-ir neuronal loss in the cortex to the general deterioration accompanying aging in F344 rats.

\section{Acknowledgements:}

The authors wish to thank Mrs. J. Janouskova for her technical assistance. This study was supported by the Grant Agency of the Czech Republic (309/07/1336), by the Grant Agency of the Ministry of Health of the Czech Republic (NR8113-4), by AV0Z50390512 and LC 554. 


\section{REFERENCES:}

Andersen, B.B., Gundersen H.J.G, 1999. Pronounced loss of cell nuclei and anisotropic deformation of thick sections. J. Microsc. 196, 69-73.

Baimbridge, K.G., Celio, M.R., Rogers, J.H., 1992. Calcium-binding proteins in the nervous system. Trends. Neurosci. 15, 303-8.

Bartos, M., Vida, I., Jonas, P., 2007. Synaptic mechanisms of synchronized gamma oscillations in inhibitory interneuron networks. Nat. Rev. Neurosci. 8, 45-56.

Bragin, A., Jando, G., Nadasdy, Z., Hetke, J., Wise, K., Buzsaki, G., 1995. Gamma (40-100 $\mathrm{Hz}$ ) oscillation in the hippocampus of the behaving rat. J. Neurosci. 15, 47-60.

Bu, J., Sathyendra, V., Nagykery, N., Geula, C., 2003. Age-related changes in calbindinD28k, calretinin, and parvalbumin-immunoreactive neurons in the human cerebral cortex. Exp. Neurol. 182, 220-31.

Buckiova, D., Popelar, J., Syka, J., 2007. Aging cochleas in the F344 rat: morphological and functional changes. Exp. Gerontol. 42, 629-38.

Buzsáki, G., Draguhn, A., 2004. Neuronal oscillations in cortical networks. Science 304, $1926-9$. 
Caspary, D.M., Milbrandt, J.C., Helfert, R.H., 1995. Central auditory aging: GABA changes in the inferior colliculus. Exp. Gerontol. 30, 349-60.

Celio, M.R., 1986. Parvalbumin in most gamma-aminobutyric acid containing neurons of the rat cerebral cortex. Science 231, 995-7.

Celio, M.R., 1990. Calbindin D-28k and parvalbumin in the rat nervous system. Neuroscience $35,375-475$.

Chernock, M.L., Larue, D.T., Winer, J.A., 2004. A periodic network of neurochemical modules in the inferior colliculus. Hear. Res. 188, 12-20.

Covenas, R., De Leon, M., Alonso, J.R., Arevalo, R., Lara, J., Aijon, J., 1991. Distribution of parvalbumin-immunoreactivity in the rat thalamus using a monoclonal antibody. Arch. Ital. Biol. 129, 199-210.

Cruikshank, S.J., Killackey, H.P., Metherate, R., 2001. Parvalbumin and calbindin are differentially distributed within primary and secondary subregions of the mouse auditory forebrain. Neuroscience 105, 553-69.

Cunningham, M.O., Hunt, J., Middleton, S., LeBeau, F.E., Gillies, M.J., Davies, C.H., Maycox, P.R., Whittington, M.A., Racca, C., 2006. Region-specific reduction in entorhinal gamma oscillations and parvalbumin-immunoreactive neurons in animal models of psychiatric illness. J. Neurosci. 26, 2767-76. 
De Felipe, J., Jones, E.G., 1992. High-Resolution light and electron microscopic immunocytochemistry of colocalized GABA and calbindin D-28k in somata and double bouquet cell axons of monkey somatosensory cortex. Eur. J. Neurosci. 4, 46-60.

De Jong, G.I., Naber, P.A., Van der Zee, E.A., Thompson, L.T., Disterhoft, J.F., Luiten, P.G., 1996. Age-related loss of calcium binding proteins in rabbit hippocampus. Neurobiol. Aging $17,459-65$.

Di Loreto Jr., D., Cox, C., Grover, D.A., Lazar, E., del Cerro, C., del Cerro, M., 1994. The influences of age, retinal topography, and gender on retinal degeneration in the Fischer 344 rat. Brain. Res. 647, 181-91.

Freund, T.F., Buzsaki, G., 1996. Interneurons of the hippocampus. Hippocampus 6, 347-470.

Foster, T.C., 2007. Calcium homeostasis and modulation of synaptic plasticity in the aged brain. Aging Cell 6, 319-25.

Fukuda, T., Kosaka, T., Singer, W., Galuske, R.A., 2006. Gap junctions among dendrites of cortical GABAergic neurons establish a dense and widespread intercolumnar network. J. Neurosci. 26, 3434-43.

Gundersen, H.J., Bagger, P., Bendtsen, T.F., Evans, S.M., Korbo, L., Marcussen, N., Møller, A., Nielsen, K., Nyengaard, J.R., Pakkenberg, B., et al., 1988. The new stereological tools: disector, fractionator, nucleator and point sampled intercepts and their use in pathological research and diagnosis. APMIS 96, 857-81. 
Harker, K.T., Whishaw, I.Q., 2002. Place and matching-to-place spatial learning affected by rat inbreeding (Dark-Agouti, Fischer 344) and albinism (Wistar, Sprague-Dawley) but not domestication (wild rat vs. Long-Evans, Fischer-Norway). Behav. Brain. Res. 134, 467-77.

Helfert, R.H., Sommer, T.J., Meeks, J., Hofstetter, P., Hughes, L.F., 1999. Age-related synaptic changes in the central nucleus of the inferior colliculus of Fischer-344 rats. J. Comp. Neurol. 406, 285-98.

Hwang, I.K., Kim, D.S., Lee, H.Y., Lee, J.Y., Choi, G.P., Lee, D.I., Kim, J.D., Lee, Y.B., Sohn, H.S., Kang, T.C., Won, M.H., 2003. Age-related changes of parvalbumin immunoreactive neurons in the rat main olfactory bulb. Mol. Cells. 16, 302-6.

Idrizbegovic, E., Canlon, B., Bross, L.S., Willott, J.F., Bogdanovic, N., 2001. The total number of neurons and calcium binding protein positive neurons during aging in the cochlear nucleus of CBA/CaJ mice: a quantitative study. Hear. Res. 158, 102-15.

Idrizbegovic, E., Bogdanovic, N., Viberg, A., Canlon, B., 2003. Auditory peripheral influences on calcium binding protein immunoreactivity in the cochlear nucleus during aging in the C57BL/6J mouse. Hear. Res. 179, 33-42.

Idrizbegovic, E., Bogdanovic, N., Willott, J.F., Canlon, B., 2004. Age-related increases in calcium-binding protein immunoreactivity in the cochlear nucleus of hearing impaired C57BL/6J mice. Neurobiol. Aging 25, 1085-93. 
Jones, E.G., 2003. Chemically defined parallel pathways in the monkey auditory system. Ann. N.Y. Acad. Sci. 999, 218-33.

Kawaguchi, Y., Kubota, Y., 1998. Neurochemical features and synaptic connections of large physiologically-identified GABAergic cells in the rat frontal cortex. Neuroscience 85, 677701.

Khachaturian, Z.S., 1989. The role of calcium regulation in brain aging: re-examination of a hypothesis. Aging 1, 17-34.

Kishimoto, J., Tsuchiya, T., Cox, H., Emson, P.C., Nakayama, Y., 1998. Age-related changes of calbindin-D28k, calretinin, and parvalbumin mRNAs in the hamster brain. Neurobiol. Aging 19, 77-82.

Kosaka, T., Katsumaru, H., Hama, K., Wu, J.Y., Heizmann, C.W., 1987. GABAergic neurons containing the $\mathrm{Ca}^{2+}$-binding protein parvalbumin in the rat hippocampus and dentate gyrus. Brain. Res. 419, 119-30.

Krzywkowski, P., De Bilbao, F., Senut, M.C., Lamour, Y., 1995. Age-related changes in parvalbumin- and GABA-immunoreactive cells in the rat septum. Neurobiol. Aging 16, 2940.

La Sarge, C.L., Montgomery, K.S., Tucker, C., Slaton, G.S., Griffith, W.H., Setlow, B., Bizon, J.L., 2007. Deficits across multiple cognitive domains in a subset of aged Fischer 344 rats. Neurobiol. Aging 28, 928-36. 
Lewis, D.A., Hashimoto, T., Volk, D.W., 2005. Cortical inhibitory neurons and schizophrenia. Nat. Rev. Neurosci. 6, 312-24.

Ling, L.L., Hughes, L.F., Caspary, D.M., 2005. Age-related loss of the GABA synthetic enzyme glutamic acid decarboxylase in rat primary auditory cortex. Neuroscience 132, 110313.

Mayhew, T.M., Gunderesen, H.J.G., 1996. 'If you assume, you can make an ass out of u and me': a decade of the disector for stereological counting of particles in 3D space. J. Anat. 188, $1-15$.

Merrill, D.A., Chiba, A.A., Tuszynski, M.H., 2001. Conservation of neuronal number and size in the entorhinal cortex of behaviorally characterized aged rats. J. Comp. Neurol. 438, 445-56.

O'Neill, W.E., Zettel, M.L., Whittemore, K.R., Frisina, R.D., 1997. Calbindin D-28k immunoreactivity in the medial nucleus of the trapezoid body declines with age in C57BL/6, but not CBA/CaJ, mice. Hear. Res. 112, 158-66.

Oler, J.A., Markus, E.J., 1998. Age-related deficits on the radial maze and in fear conditioning: hippocampal processing and consolidation. Hippocampus. 8, 402-15.

Ouda, L., Nwabueze-Ogbo, F.C., Druga, R., Syka, J., 2003. NADPH-diaphorase-positive neurons in the auditory cortex of young and old rats. Neuroreport 14, 363-6. 
Paxinos, G., Watson, C., 1998. The rat brain in stereotaxic coordinates. Academic Press, New York.

Penschuck, S., Flagstad, P., Didriksen, M., Leist, M., Michael-Titus, A.T., 2006. Decrease in parvalbumin-expressing neurons in the hippocampus and increased phencyclidine-induced locomotor activity in the rat methylazoxymethanol (MAM) model of schizophrenia. Eur. J. Neurosci. 23, 279-84.

Poe, B.H., Linville, C., Brunso-Bechtold, J., 2001. Age-related decline of presumptive inhibitory synapses in the sensorimotor cortex as revealed by the physical disector. J. Comp. Neurol. 406, 285-98.

Popelar, J., Groh, D., Mazelova, J., Syka, J., 2003. Cochlear function in young and adult Fischer 344 rats. Hear. Res. 186, 75-84.

Popelar, J., Groh, D., Pelanova, J., Canlon, B., Syka, J., 2006. Age-related changes in cochlear and brainstem auditory functions in Fischer 344 rats. Neurobiol. Aging 27, 490-500.

Shetty, A.K., Turner, D.A., 1998. Hippocampal interneurons expressing glutamic acid decarboxylase and calcium-binding proteins decrease with aging in Fischer 344 rats. J. Comp. Neurol. 394, 252-69.

Shi, L., Argenta, A.E., Winseck, A.K., Brunso-Bechtold, J.K., 2004. Stereological quantification of GAD-67-immunoreactive neurons and boutons in the hippocampus of middle-aged and old Fischer 344 x Brown Norway rats. J. Comp. Neurol. 478, 282-91. 
Stemmelin, J., Lazarus, C., Cassel, S., Kelche, C., Cassel, J.C., 2000. Immunohistochemical and neurochemical correlates of learning deficits in aged rats. Neuroscience 96, 275-89.

Tardif, E., Chiry, O., Probst, A., Magistretti, P.J., Clarke, S., 2003. Patterns of calciumbinding proteins in human inferior colliculus: identification of subdivisions and evidence for putative parallel systems. Neuroscience 116, 1111-21.

Toescu, E.C., Verkhratsky, A., Landfield, P.W., 2004. Ca2+ regulation and gene expression in normal brain aging. Trends. Neurosci. 27, 614-20.

Verkhratsky, A., Toescu, E.C., 1998. Calcium and neuronal ageing. Trends. Neurosci. 21, 2-7.

Villarreal, J.S., Dykes, J.R., Barea-Rodriguez, E.J., 2004. Fischer 344 rats display age-related memory deficits in trace fear conditioning. Behav. Neurosci. 118, 1166-75.

West, M.J., Slomianka, L., Gundersen, H.J., 1991. Unbiased stereological estimation of the total number of neurons in the subdivisions of the rat hippocampus using the optical fractionator. Anat. Rec. 231, 482-97.

Willott, J.F., Bross, L.S., and Mc Fadden, S.L., 1994. Morphology of the inferior colliculus in C57BL/6J and CBA/J mice across the life span. Neurobiol. Aging 15, 175-183.

Woo, N.H., Lu, B., 2006. Regulation of cortical interneurons by neurotrophins: from development to cognitive disorders. Neuroscientist 12, 43-56. 
Zettel, M.L., Frisina, R.D., Haider, S.E., O'Neill, W.E., 1997. Age-related changes in calbindin D-28k and calretinin immunoreactivity in the inferior colliculus of CBA/CaJ and C57B1/6 mice. J. Comp. Neurol. 386, 92-110.

Zettel, M.L., O'Neill, W.E., Trang, T.T., Frisina, R.D., 2001. Early bilateral deafening prevents calretinin up-regulation in the dorsal cortex of the inferior colliculus of aged CBA/CaJ mice. Hear. Res. 158, 131-8.

Zilles, K., 1985. The Cortex of the Rat, A Stereotaxic Atlas. Springer-Verlag, Berlin. 


\section{Legends to figures:}

\section{Fig. $1(\mathbf{A}, \mathbf{B}, \mathbf{C})$}

Topographical overview of the IC, MGB, AC and their subdivisions. Drawings adapted from Paxinos and Watson (1998) and Zilles (1985); (A) - bregma -8.8 mm, (B) - bregma -5.0 mm, (C) - bregma -4.8 mm. Par - Parietal cortex; Hip - Hippocampus; PRh - Perirhinal cortex; V1,2 - Visual cortex 1,2; RSD,RSV - Retrosplenial cortex, dorsal and ventral; MGB-D,V,M - dorsal, ventral and medial division of the MGB.

Fig. 2 (A-F)

Comparison of PV immunoreactivity between young (A,C,E) and old (B,D,F) Fischer 344 rats in the central nucleus of the IC (A,B) and in the primary auditory cortex - Te 1: C,D - all layers, E,F - layers II-IV only. D and F show the reduced occurrence of PV-ir neurons in the auditory cortex of old F344 rats.

Fig. 3

Schematic lateral view of the rat brain (Fischer 344) with the indicated fields devoid of PV-ir cells within the AC in two old animals (the fields passed through all cortical layers). Dotted line - rat FG1; dashed line - rat FR2. Par - parietal cortex.

\section{Fig. 4}

Results of the quantitative evaluation of PV immunoreactivity in Long Evans (A,C,E) and Fischer 344 rats (B,D,F). Light grey columns are for young animals, dark grey columns for old animals.

A, B) Number of PV-immunoreactive neurons in the CIC, MGB, and auditory cortex (Te1 + 3) of young and old rats. C, D) Optical density of the somas of PV-immunoreactive neurons in the CIC, MGB, and auditory cortex $(\mathrm{Te} 1+3)$ of young and old rats. E, F) Mean volumes of the somas of PV-immunoreactive neurons in the CIC, MGB, and auditory cortex $(\mathrm{Te} 1+3)$ of young and old rats. 
Fig.1A

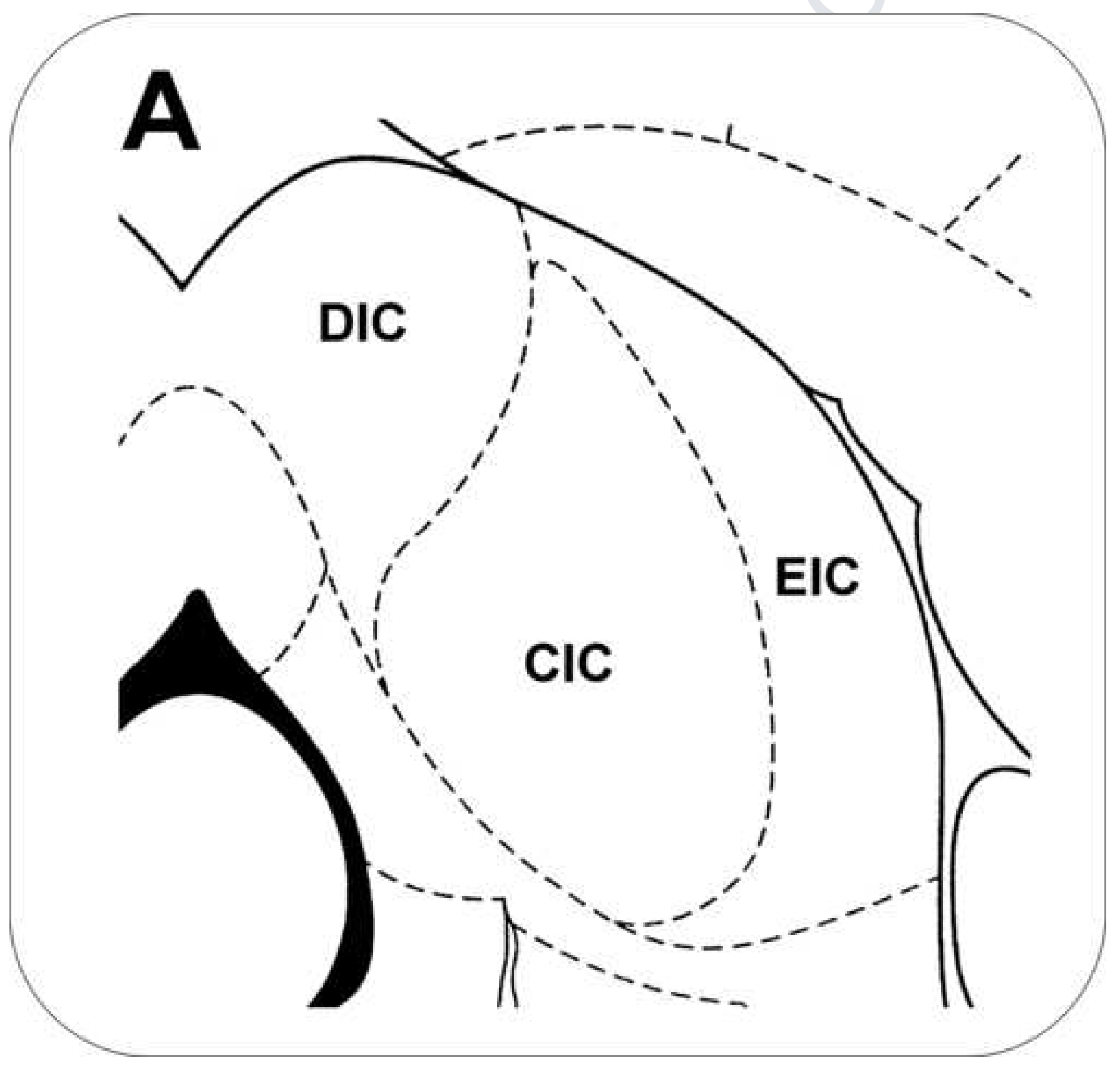


Fig.1B

MGB-M

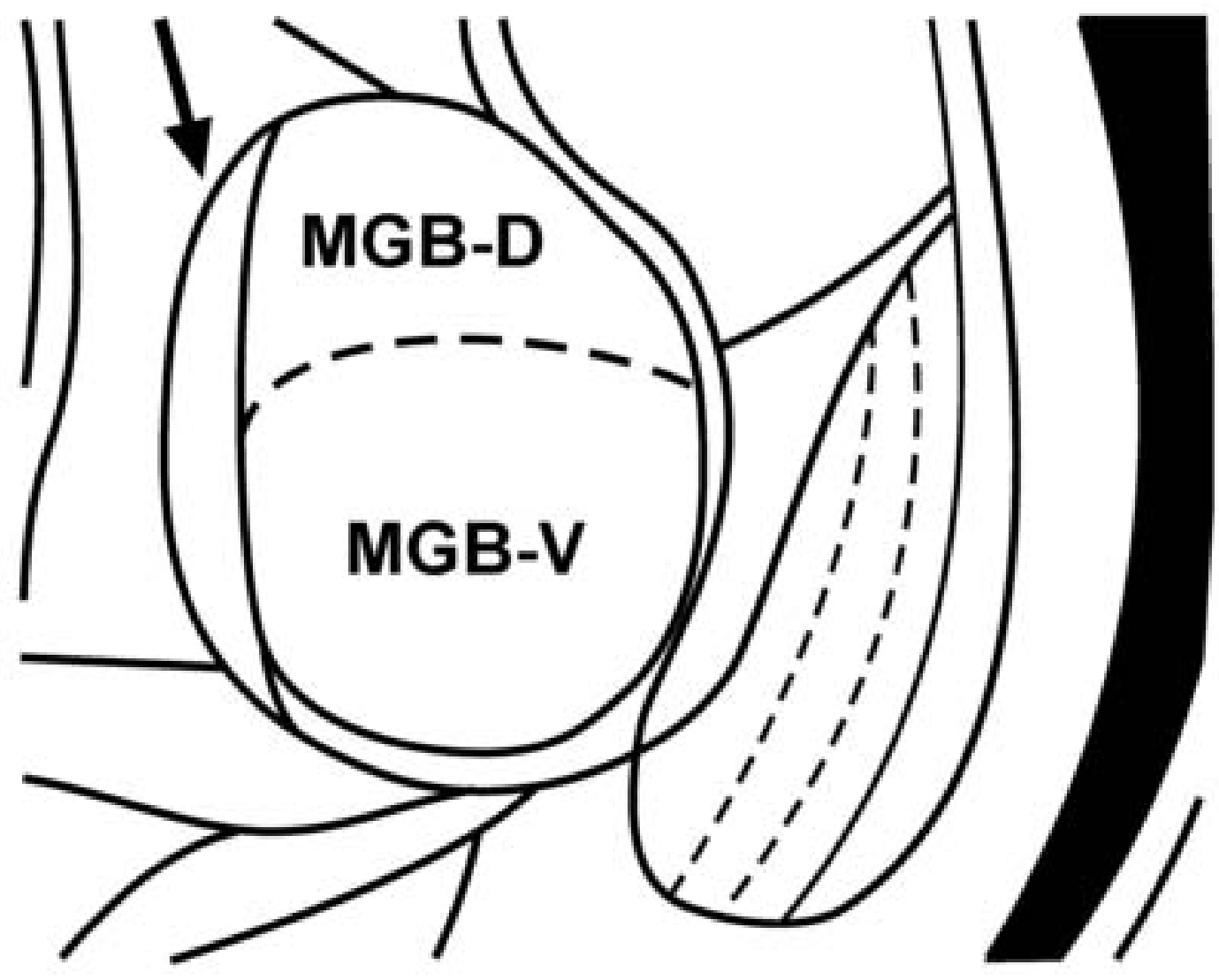


Fig.1C

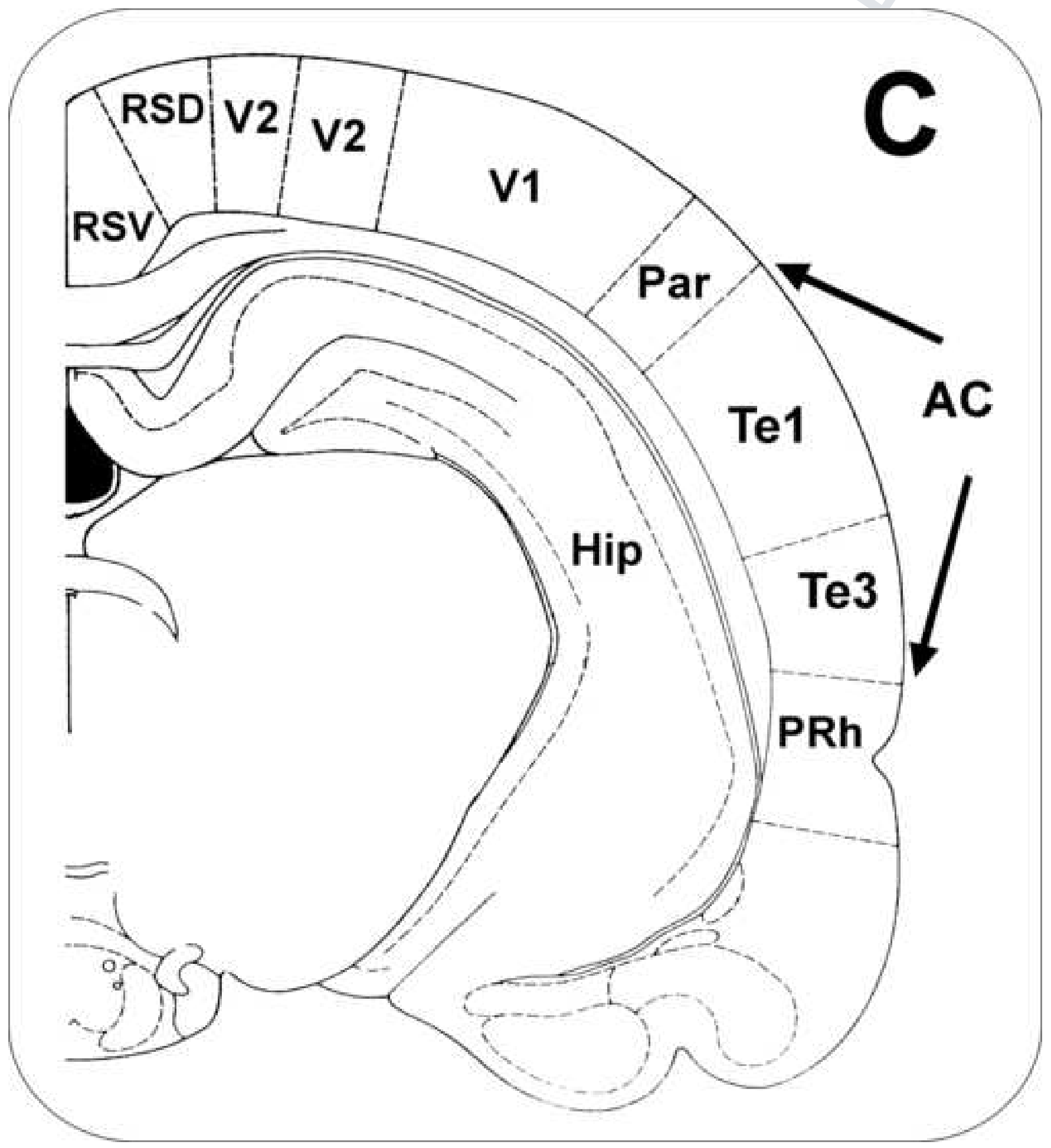


Fig.2A

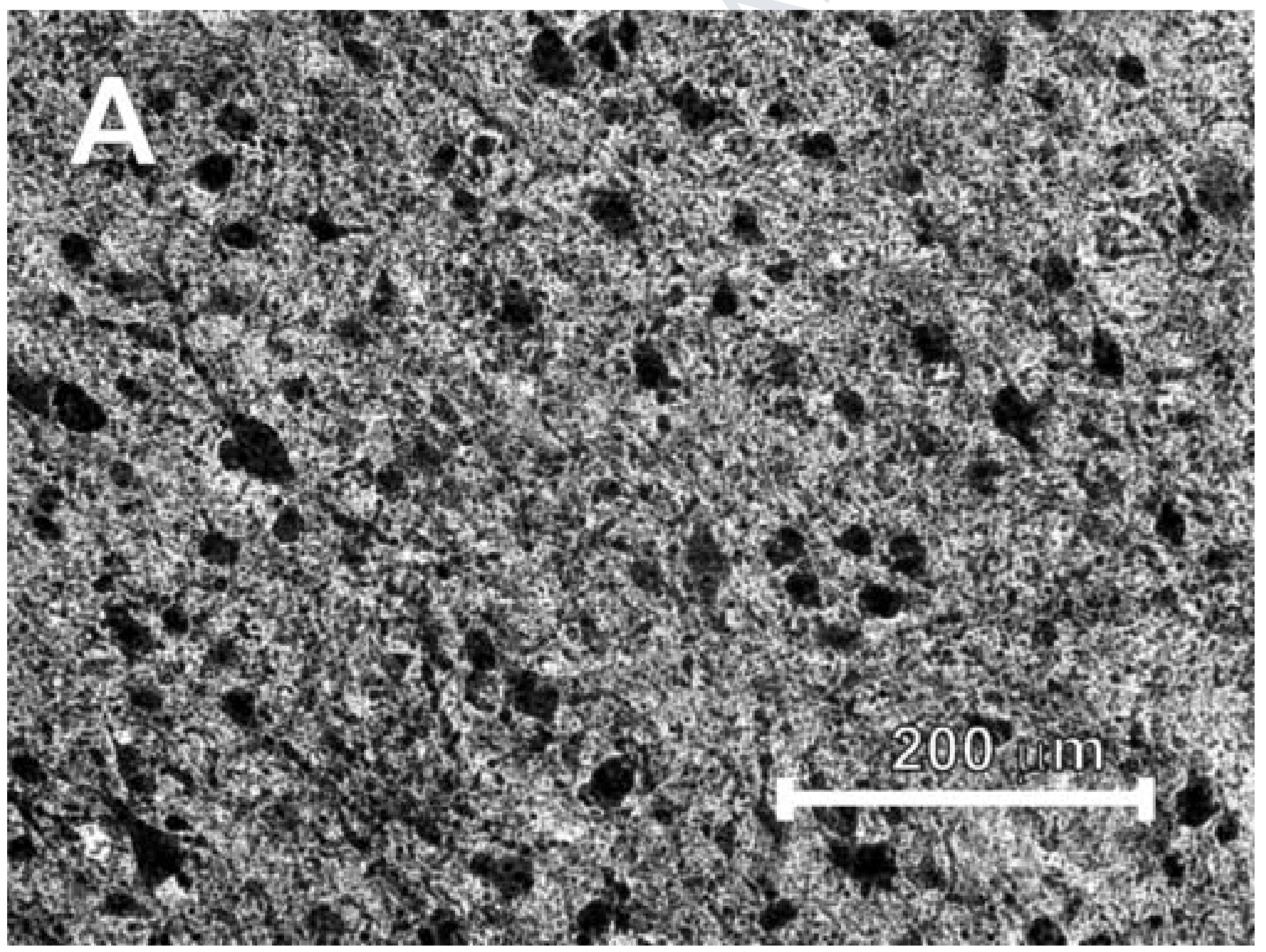


Fig.2B

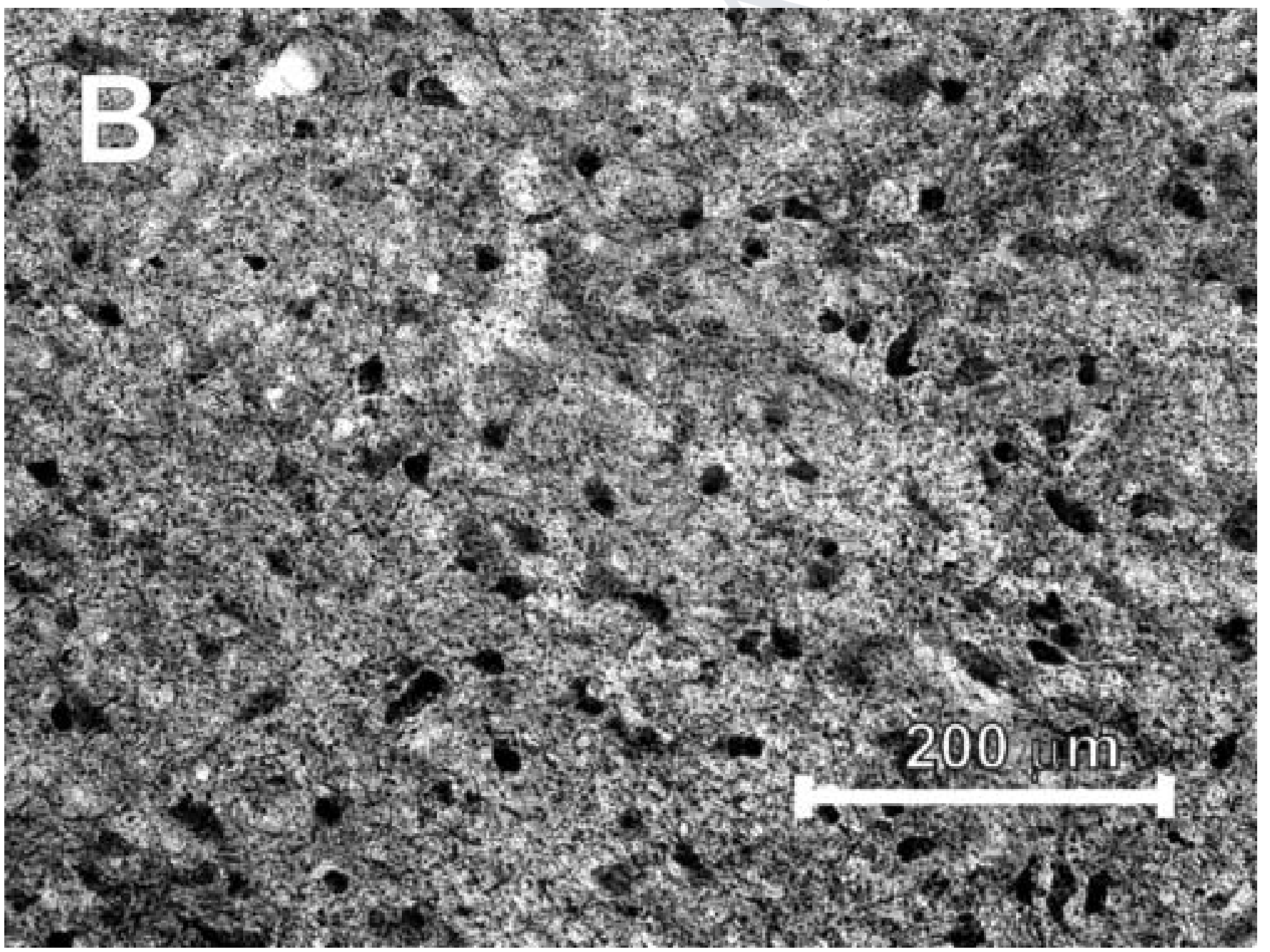


Fig.2C

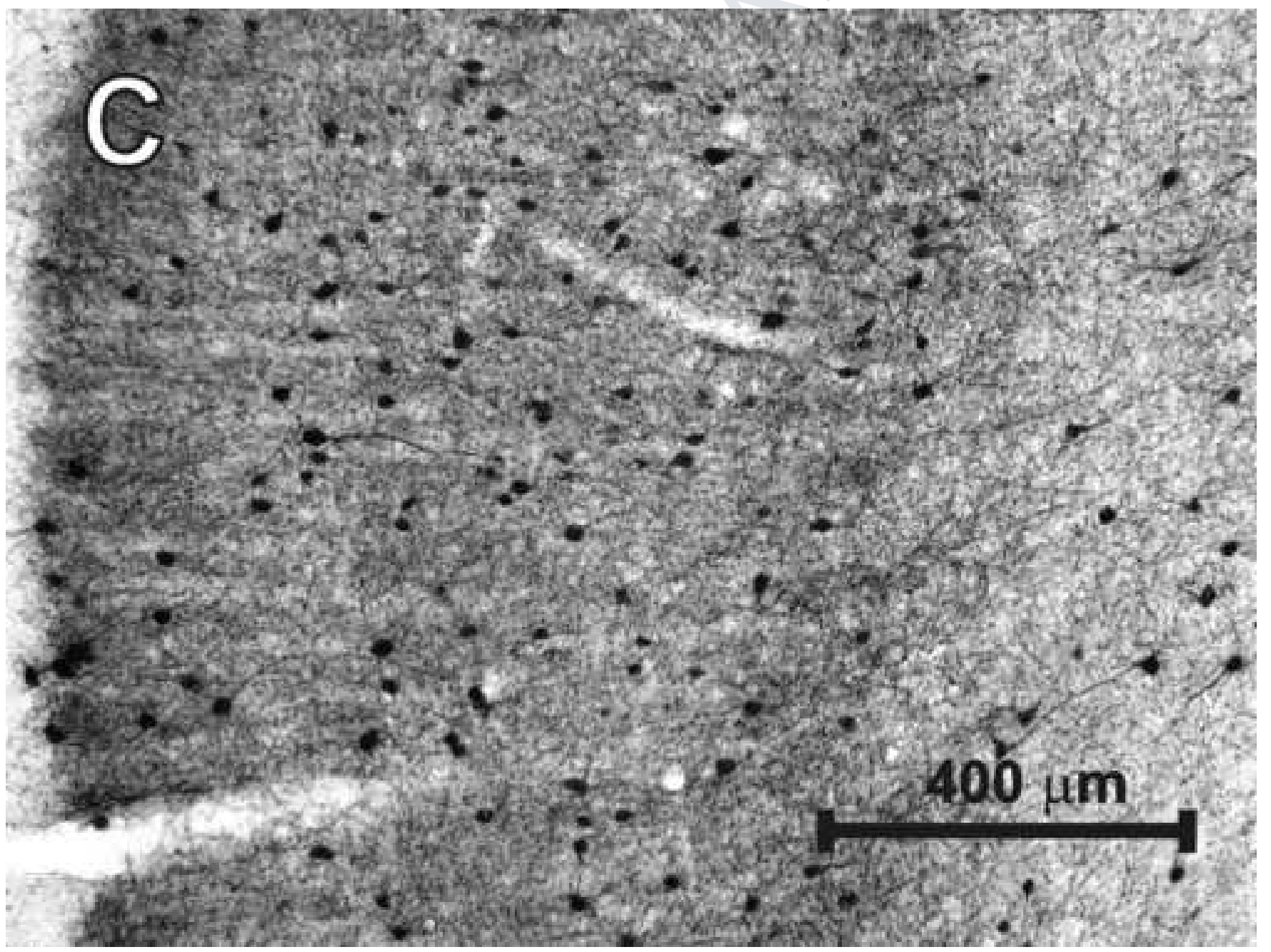




\section{Fig.2D}

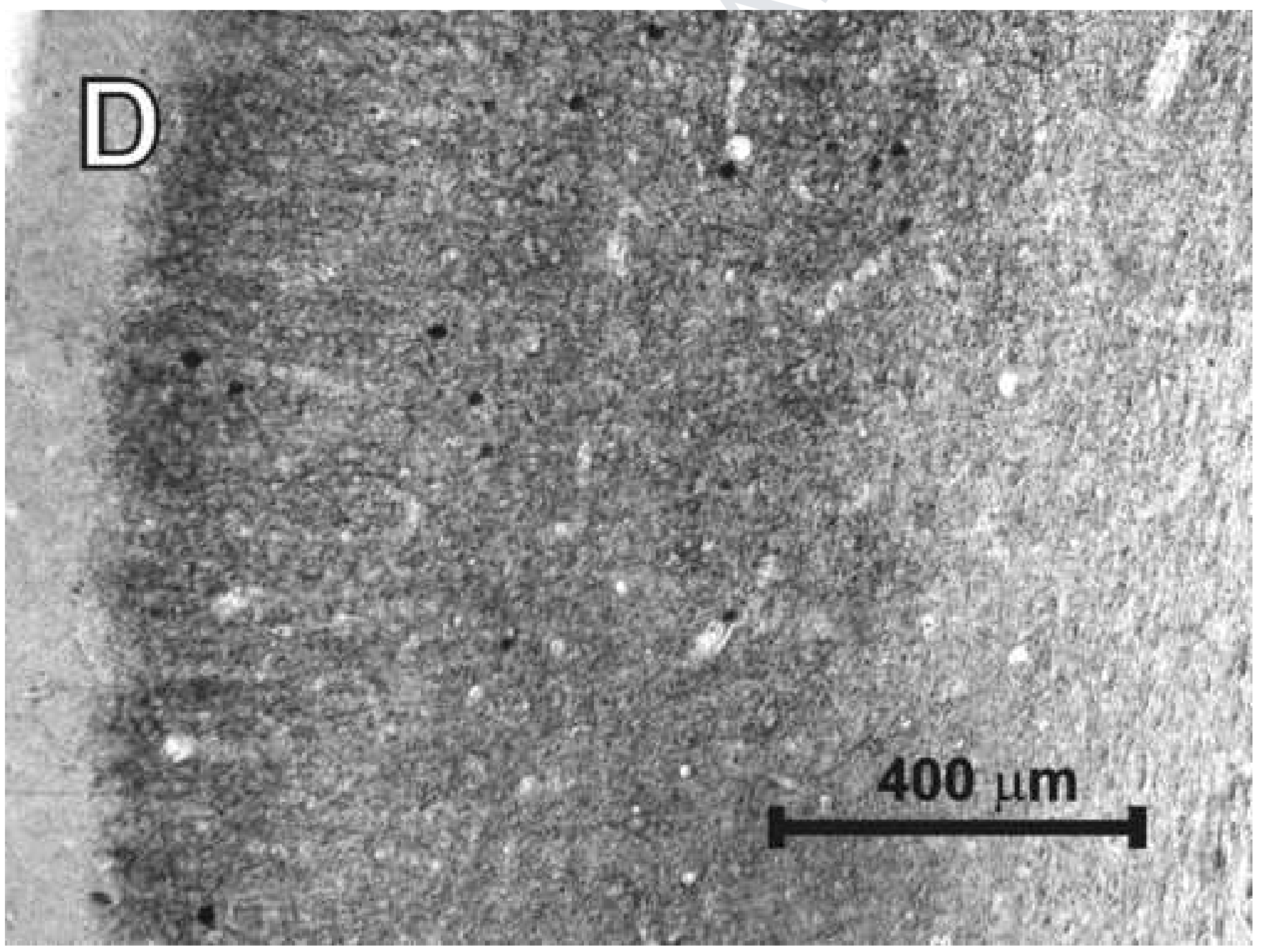


Fig.2E

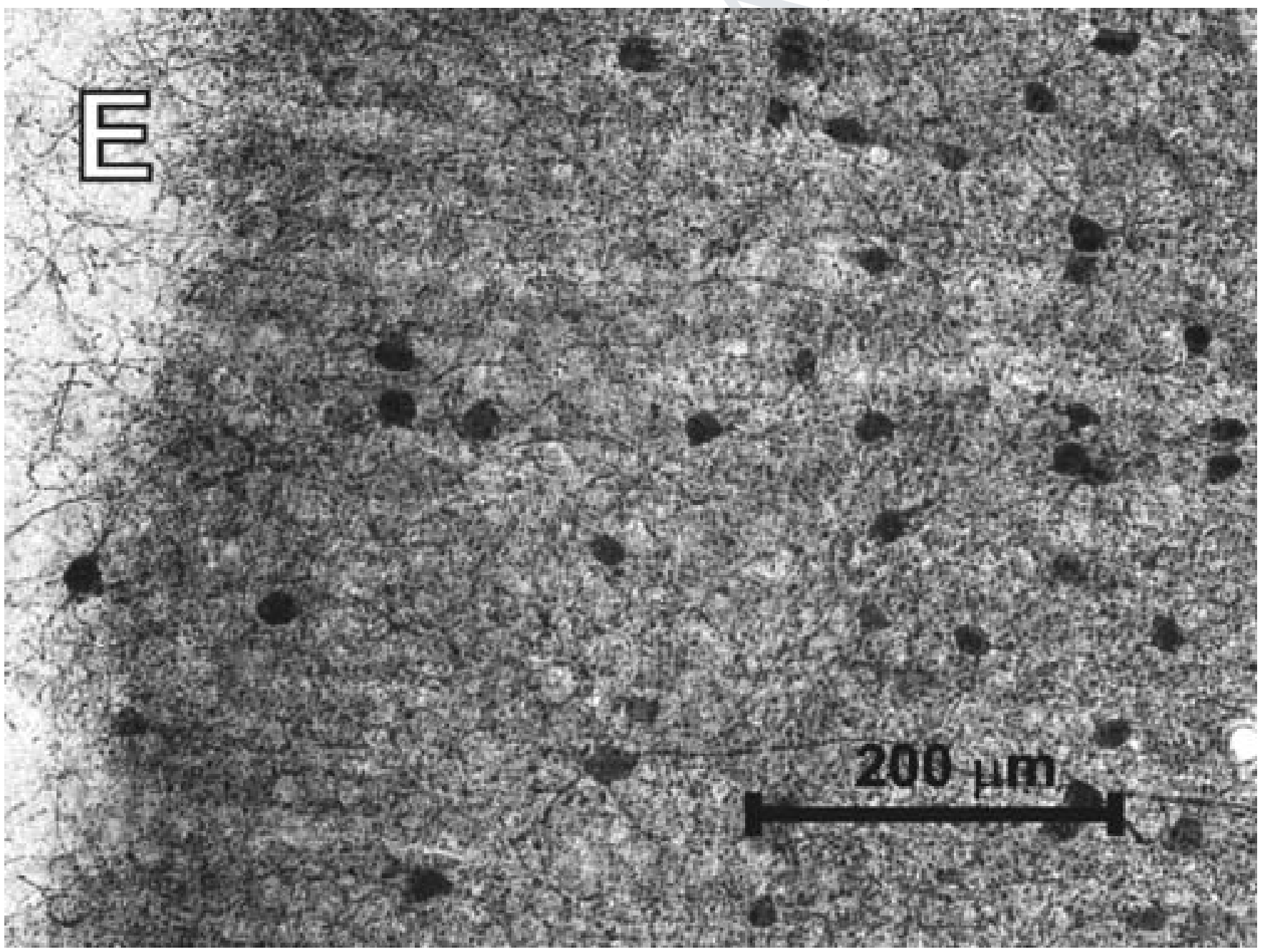


Fig.2F

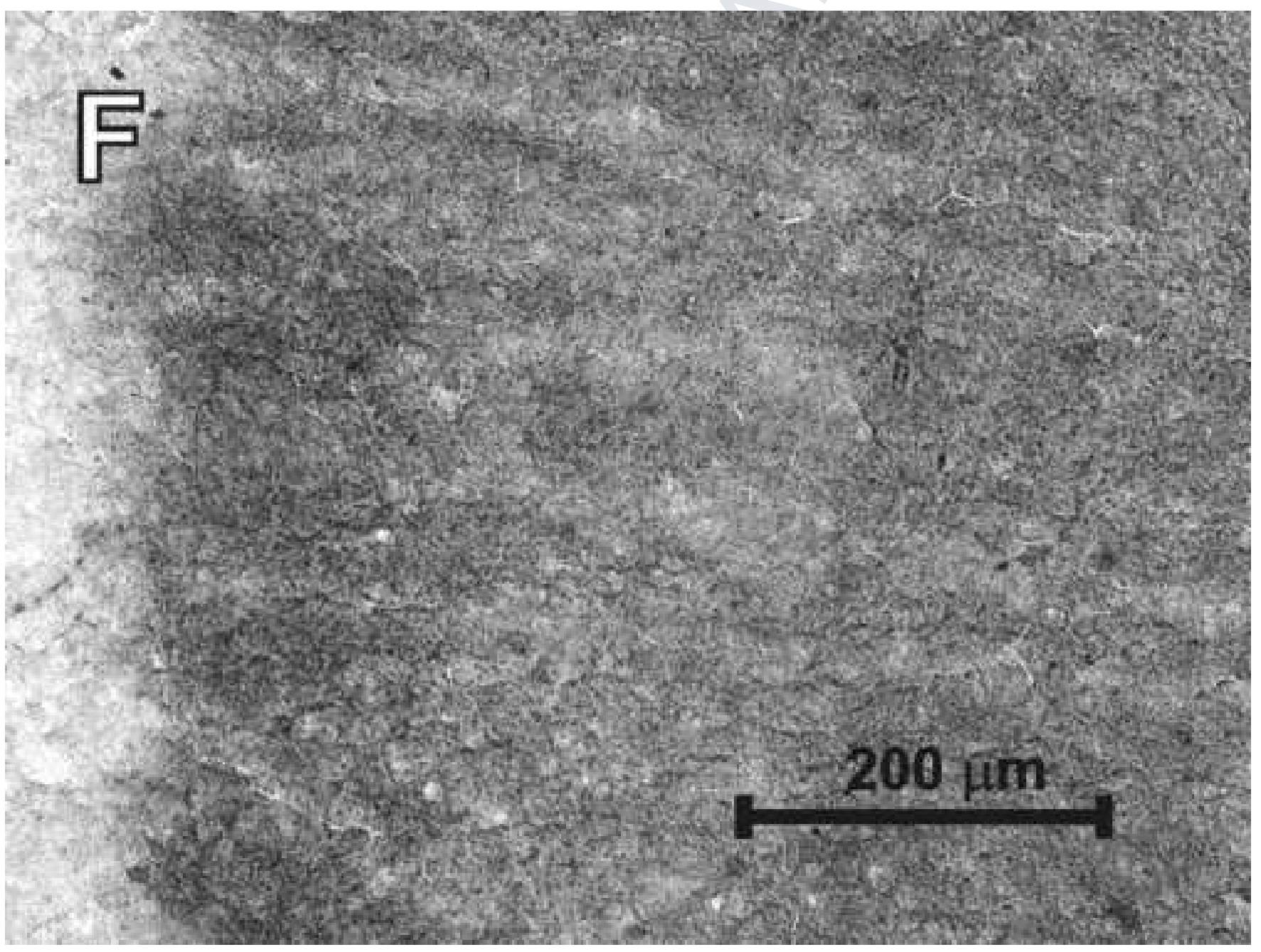


Fig.3

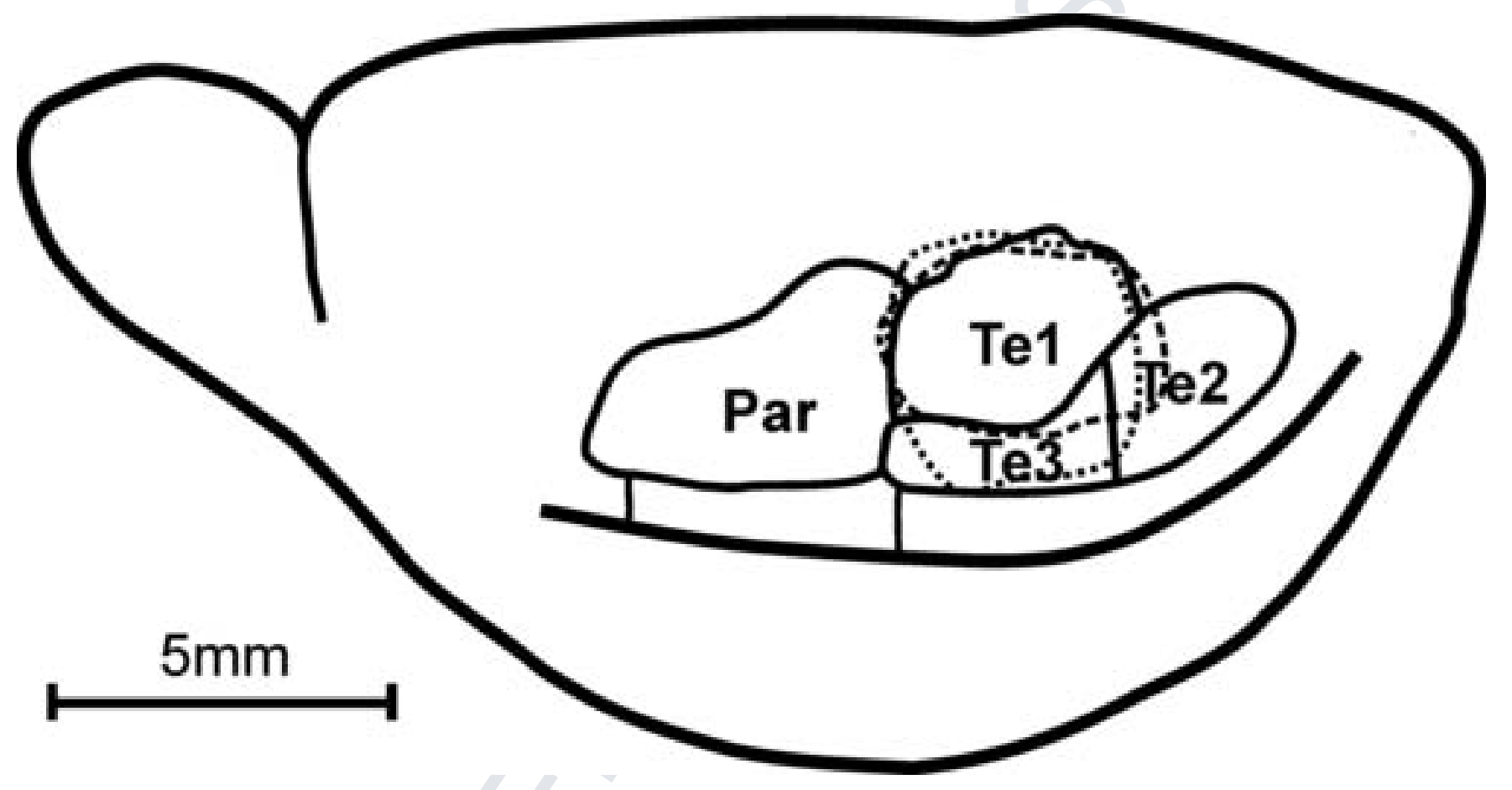


Fig.4A

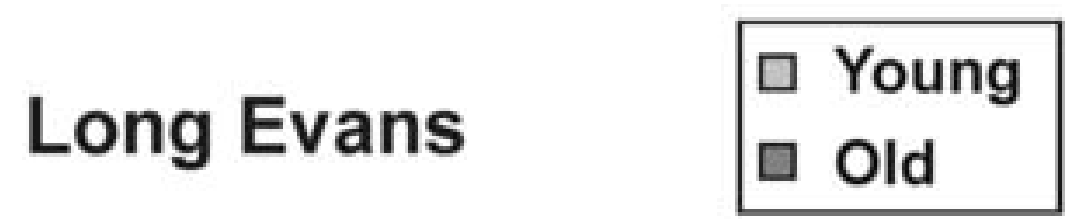

A

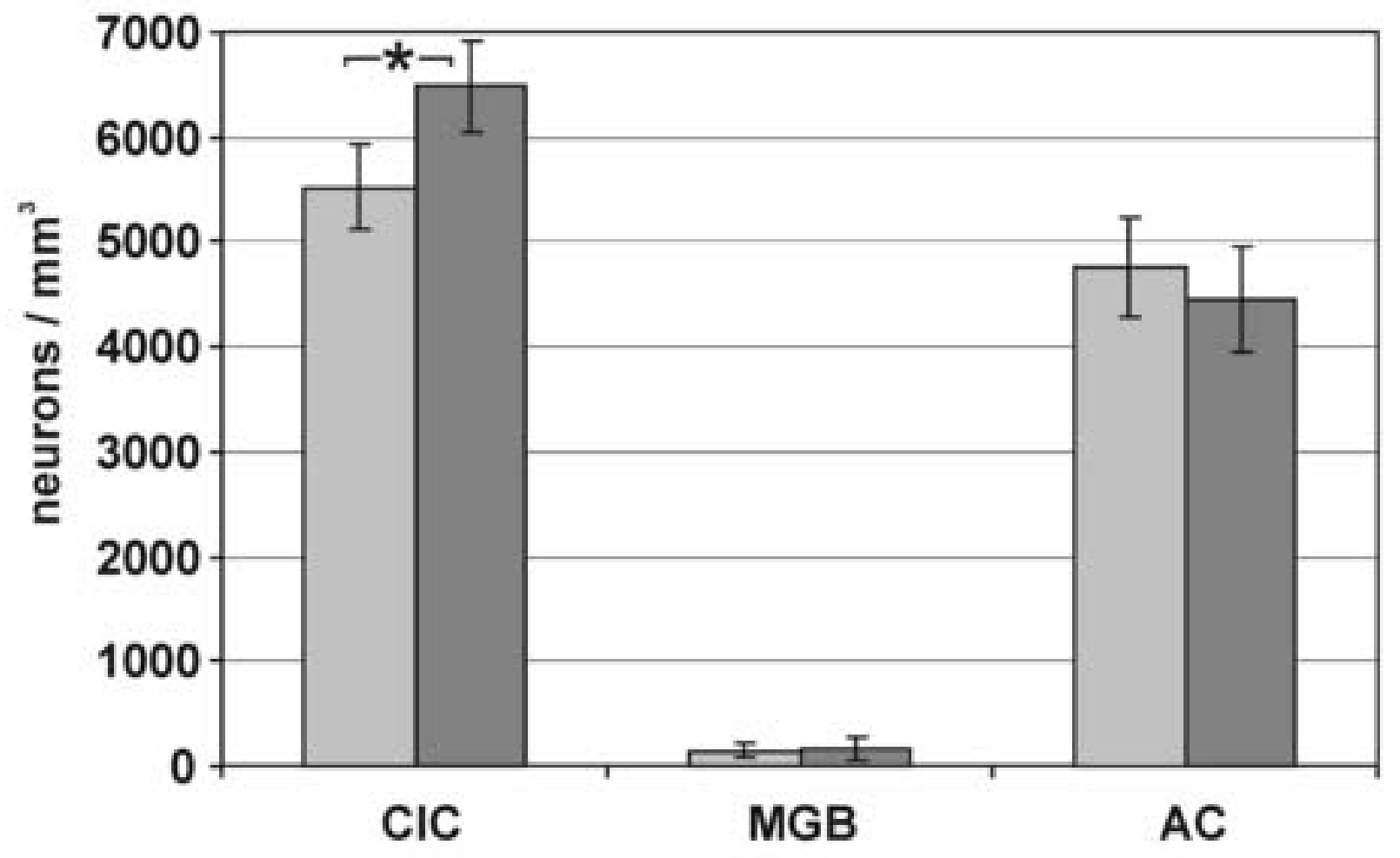


Fig.4B

Fischer 344

$\square$ Young
$\square$ Old

B

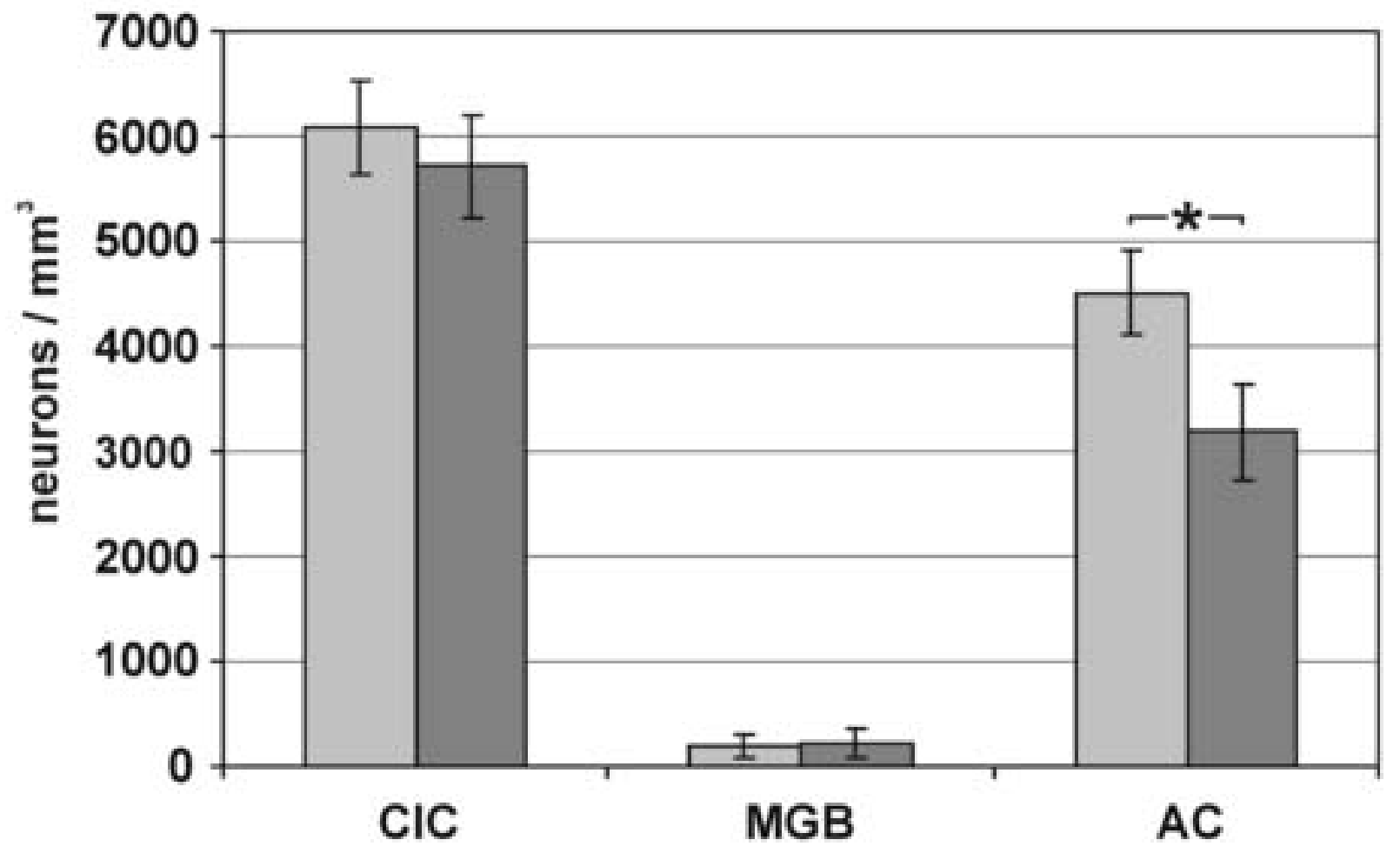


Fig.4C

C

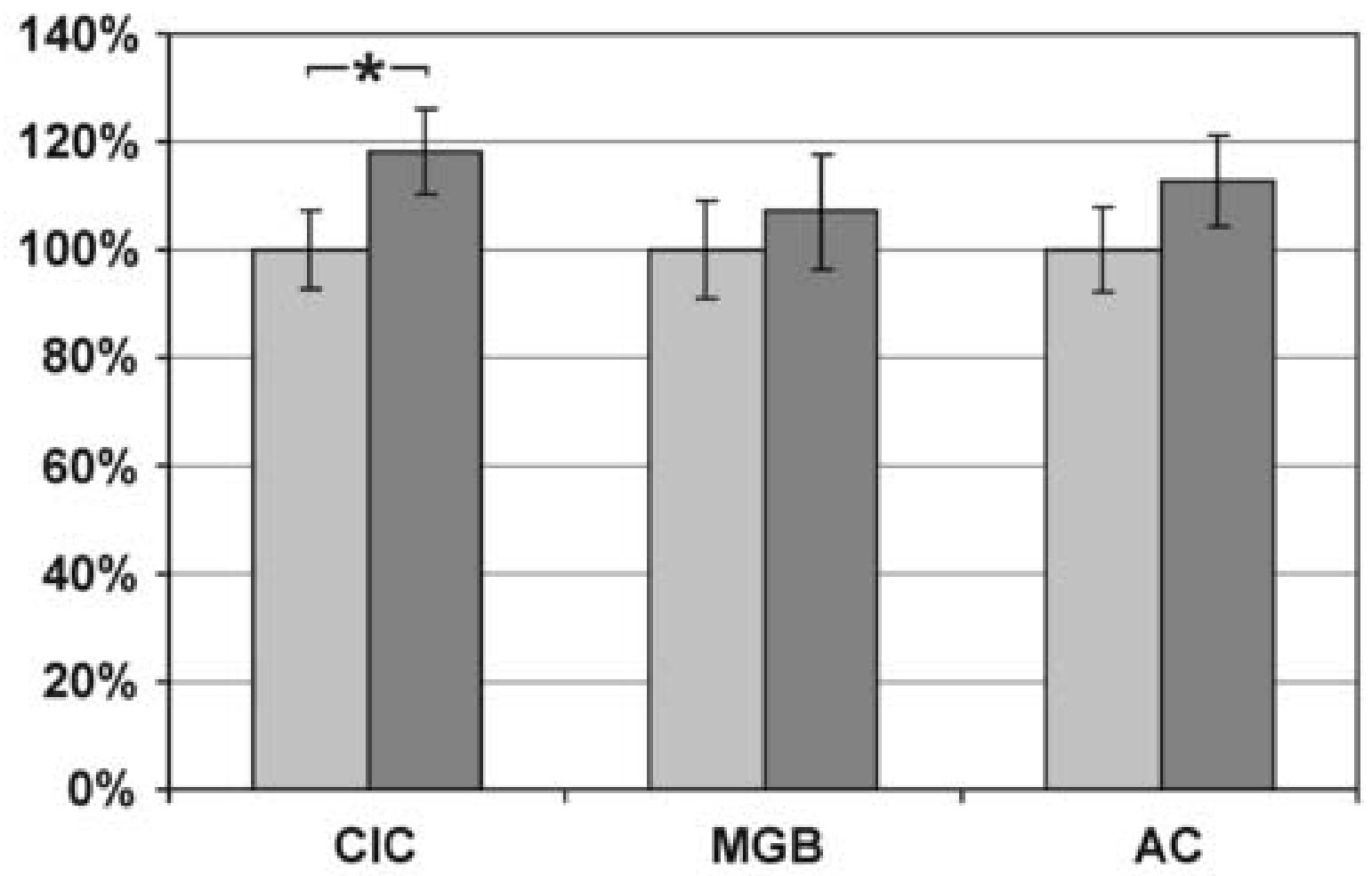


Fig.4D

D

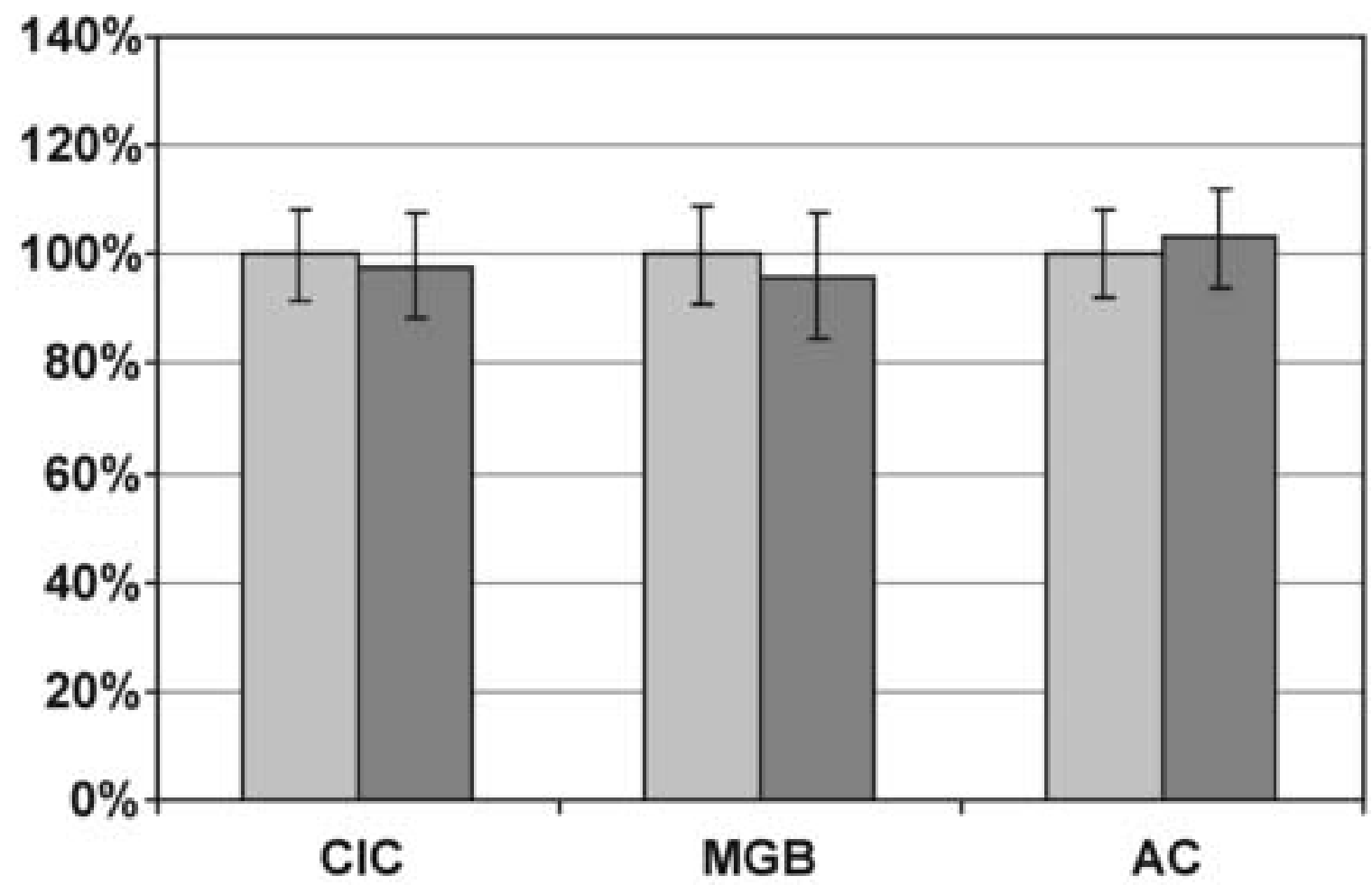


Fig.4E

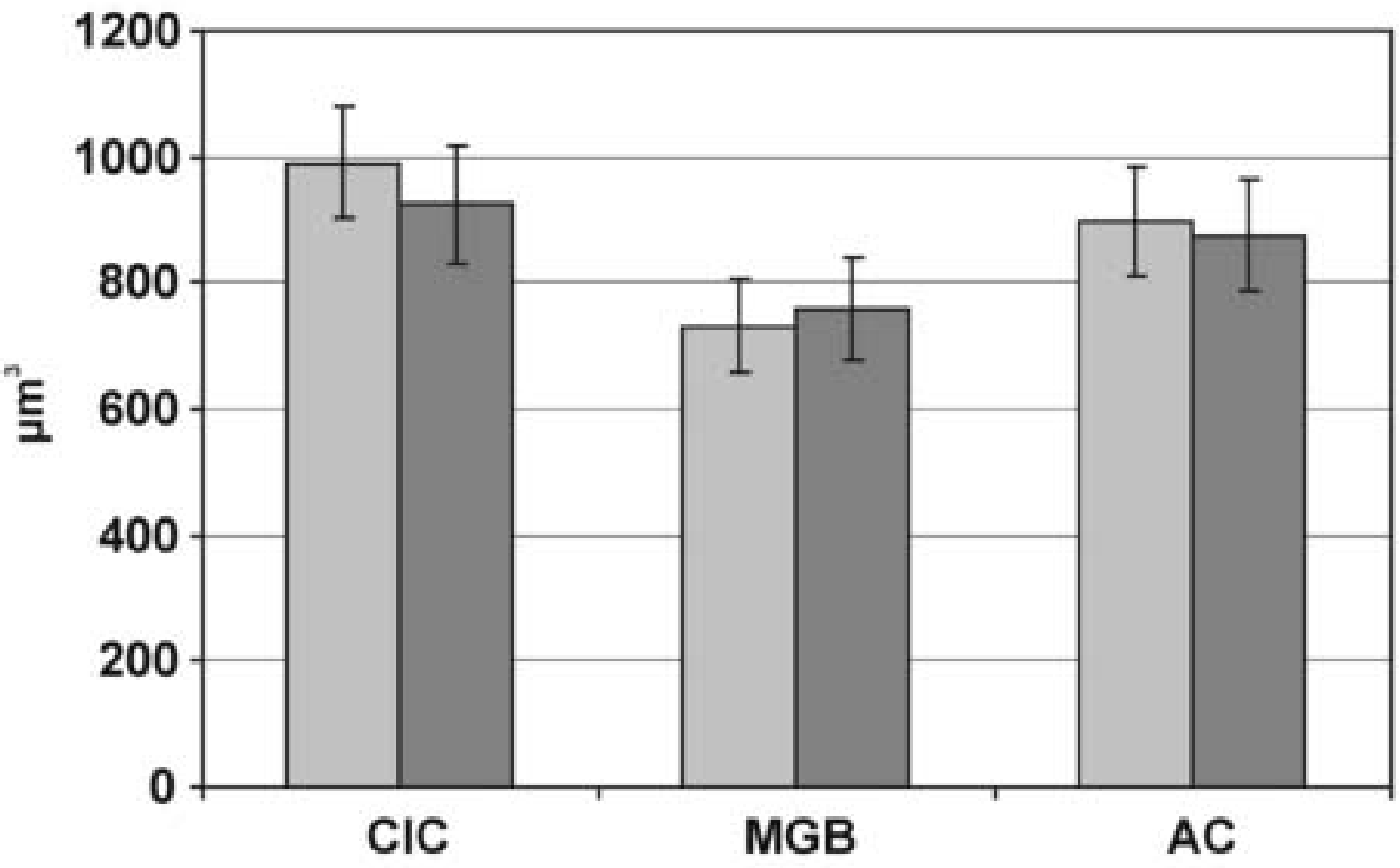


Fig.4F

F

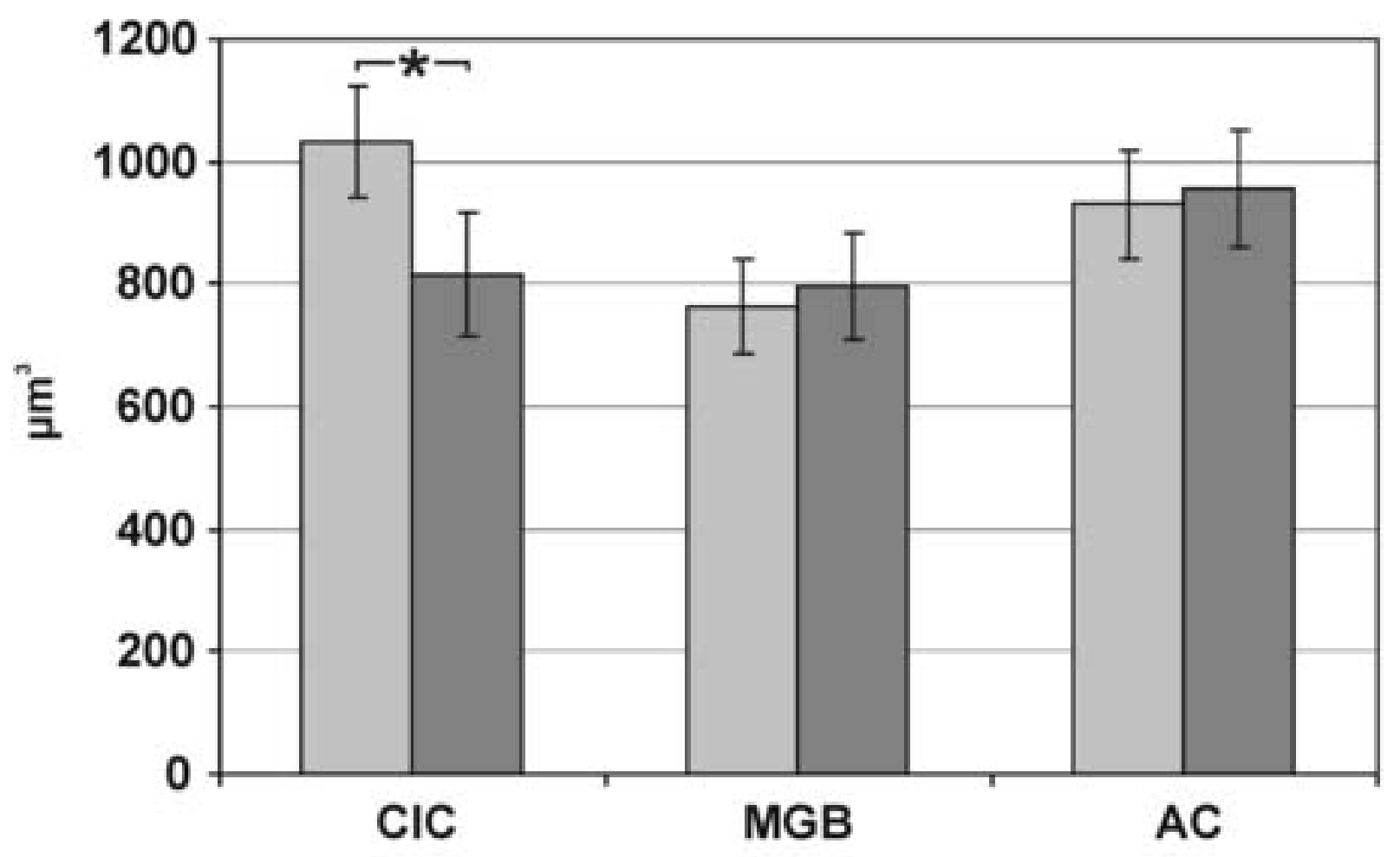

